\title{
Noble metal ion-substituted ceria as efficient oxygen storage catalysts for clean combustion of fuels
}

\author{
Rajagopalan Vijayaraghavan
}

Received: 29 March 2013/Accepted: 28 June 2013/Published online: 23 July 2013

(c) The Author(s) 2013. This article is published with open access at Springerlink.com

\begin{abstract}
Three-way catalysts, a component of automobile converters, can control auto exhaust emissions by its capacity of converting $\mathrm{CO}$, un-burnt hydrocarbon and oxides of nitrogen $\left(\mathrm{NO}_{x}\right)$ into less harmful $\mathrm{CO}_{2}, \mathrm{H}_{2} \mathrm{O}$ and $\mathrm{N}_{2}$ simultaneously. This process is efficient only when the $A / F$ ratio is at 14.7 . To widen the ratio for better chemical control, oxygen storage catalysts (OSC) based on $\mathrm{CeO}_{2}$, capable of three-way action, are employed in converters along with conventional catalysts. In this article, the enhanced activity of noble metal ion incorporated/dispersed $\mathrm{CeO}_{2}$ catalysts towards three-way action over conventional metal particles dispersed (in a matrix) catalysts is illustrated. The better performance of the metal ion dispersed catalysts is attributed to better dispersion of active metal ion sites over the reducible matrix like $\mathrm{CeO}_{2}$, leading to many-fold increase in the number of active sites.
\end{abstract}

Keywords Oxygen storage capacity $\cdot \mathrm{Pd}^{2+} / \mathrm{CeO}_{2}$ catalysts $\cdot \mathrm{CO}$ oxidation $\cdot$ XPS $\cdot$ Temperature programmed reduction

\section{Introduction}

To abate pollution due to emissions from automobiles, auto exhaust catalysts containing noble metals such as Pt, Pd and

R. Vijayaraghavan $(\bowtie)$

School of Advanced Sciences, Centre for Nano Materials,

VIT University, Vellore 632 014, India

e-mail: rvijayaraghavan@vit.ac.in
Rh dispersed in $\gamma-\mathrm{Al}_{2} \mathrm{O}_{3}$ as the support have been employed in converters. $\gamma-\mathrm{Al}_{2} \mathrm{O}_{3}$ is mixed with $30 \%$ by weight of $\mathrm{Ce}_{0.7} \mathrm{Zr}_{0.3} \mathrm{O}_{2}$ as an oxygen storage material [1]. Although ceria-based catalysts as oxygen storage catalysts (OSC) are known since 1980s for the three way action, various approaches are adopted to widen/control the $A / F$ ratio at 14.7 where the concentrations of oxidizing and reducing species are equal. Systems monitor the dynamic $A / F$ ratio but monitoring through chemical control is a more versatile method. In this method, the operating window is widened by the OSC through the storage of oxygen in the oxygenrich condition and releasing oxygen in the lean condition in situ. In this context, $\mathrm{CeO}_{2}$ has been an important oxygen storage material in TWC $[2,3]$. The reactions are

$$
\begin{aligned}
& \mathrm{CeO}_{2} \rightarrow \mathrm{CeO}_{2-\delta}+\delta / 2 \mathrm{O}_{2} \text { (oxygen lean region) } \\
& \mathrm{CeO}_{2-\delta}+\delta / 2 \mathrm{O}_{2} \rightarrow \mathrm{CeO}_{2} \text { (oxygen-rich region) }
\end{aligned}
$$

The amount of oxygen released in the first reaction and the oxygen consumed in the second reaction is referred to as the oxygen storage capacity of the ceria material $[4,5]$. The reversible intercalation of oxygen is derived from its structural feature.

Ceria crystallizes in fluorite structure $\left(\mathrm{CaF}_{2}\right)$ in which the $\mathrm{Ce}^{4+}$ ions form the face centred cubic (FCC) structure with the tetrahedral holes occupied by oxide ions and the octahedral holes remaining vacant. The unit cell is shown in Fig. 1.

Oxygen deficient phase of $\mathrm{CeO}_{2-\delta}$ has been studied using X-ray diffraction (XRD), temperature programmed reduction (TPR) and magnetic measurements [6, 7]. Noble metals such as Pt, $\mathrm{Pd}$ and $\mathrm{Rh}$, bimetallic $\mathrm{Pt}-\mathrm{Rh}$ are dispersed as nanocrystalline metal particles or metallic ions into the matrix of OSC materials with gamma-alumina support $\left(\mathrm{Ce}_{0.7} \mathrm{Zr}_{0.3} \mathrm{O}_{2}\right.$ with alumina) 


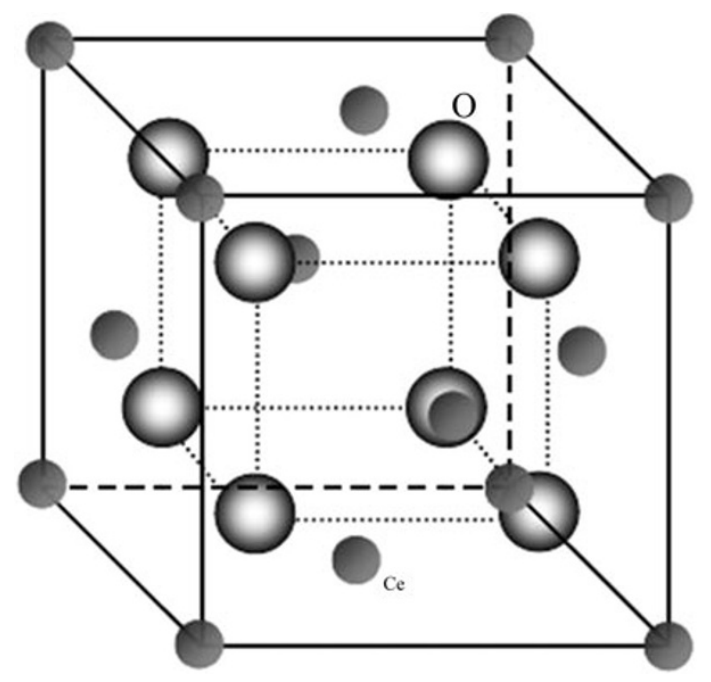

Fig. 1 Unit cell of $\mathrm{CeO}_{2}$

\section{Experimental}

Synthesis of noble metal ion substituted ceria is carried out by solution combustion method [8]. A typical procedure is as follows. Stoichiometric quantities of ceric ammonium nitrate, $\mathrm{H}_{2} \mathrm{PdCl}_{6}$ and a fuel, urea or oxaldihydrazide are dissolved in minimum amount of water. This solution mixture is introduced into a preheated furnace kept at $500{ }^{\circ} \mathrm{C}$. The mixture undergoes controlled combustion reaction resulting in the crystalline product within $5 \mathrm{~min}$ of the reaction. The products are characterized by powder XRD recorded with a Bruker D8-Advanced machine with a slow scan. X-ray photoelectron spectroscopy (XPS) was carried out by ESCA-3 Mark II VG Scientific Spectrometer using Al Ka radiation $(1,486.6 \mathrm{eV})$. Binding energies reported are with respect to $\mathrm{C}(1 \mathrm{~S})$ at $285 \mathrm{eV}$ and were measured with a precision of $\neq 0.2 \mathrm{eV}$. The catalytic reactions were done in a temperature programmed reaction system equipped with a quadrupole mass spectrometer SX 200 (VG Scientific Ltd, England) and a Gas Chromatograph (Mayura Analytical, India) equipped with chromosorb 101 column using a thermal conductivity detector. Catalysts were placed between glass wool plugs in the centre of a quartz tube which is inserted into the furnace appropriately. The furnace is controlled by a Eurotherm temperature controller connected by a chromel-alumel thermocouple. The gaseous products were sampled through a fine leak valve via a differential pumped sampling chamber to an ultra high vacuum (UHV) system employing a quadrupole mass spectrometer. Gases were analysed by GC. Mass balance confirmed the amount of evolved gases.

\section{Results and discussion}

Figure 2 shows the XRD pattern of nanocrystalline $\mathrm{CeO}_{2}$ by combustion method. It reveals the formation of nanocrystalline $\mathrm{CeO}_{2}$ with crystallite size of about $15-20 \mathrm{~nm}$, calculated using Scherrer formula. Pd loading into ceria is carried out by the same combustion method starting from corresponding $\mathrm{Ce}$ and Pd salts.

$\mathrm{Pd}$ incorporated ceria exhibits sharper peaks indicating bigger crystallite size $(100-110 \mathrm{~nm})$. The cubic lattice parameters of $\mathrm{CeO}_{2}$ and $\mathrm{Ce}_{0.98} \mathrm{Pd}_{0.02} \mathrm{O}_{2-\delta}$ are 5.413 (2) $\AA$ and 5.4107(3) $\AA$ respectively, indicating the incorporation of smaller $\mathrm{Pd}^{2+}$ into the site of bigger $\mathrm{Ce}^{4+}$. The diffraction patterns clearly show the absence of Pd metal or PdO within the detectable limits of XRD. The XRD patterns are the same before and after $\mathrm{CO}$ oxidation reaction.

The XPS spectrum of $\mathrm{Pd}^{2+}$ substituted $\mathrm{CeO}_{2}$ along with that of $\mathrm{Pd}$ metal, $\mathrm{PdO}$ and $\mathrm{PdCl}_{2}$ is shown in Fig. 3. The binding energies of $\mathrm{Pd} 4 \mathrm{~d}$ peak in $2 \%$ doped $\mathrm{Pd} / \mathrm{CeO}_{2}$ are close to that of $\mathrm{Pd} 4 \mathrm{~d}$ states in $\mathrm{PdCl}_{2}$. This indicates that $\mathrm{Pd}$ in ceria is present as $\mathrm{Pd}^{2+}$, in contrast to metal particles dispersed in a matrix like $\mathrm{Al}_{2} \mathrm{O}_{3}$. The redox matrix of $\mathrm{CeO}_{2}$ facilitates the existence of ionic form of $\mathrm{Pd}$ in the support and such ionic species can enhance the number of active sites for the catalytic reactions.

The XPS spectrum of $\mathrm{Ce}$ (Fig. 4) in $2 \%$ Pd-doped $\mathrm{CeO}_{2}$ shows satellite peaks (marked) corresponding to $\mathrm{CeO}_{2}$ with $\mathrm{Ce}$ in the +4 oxidation state [9] in the as-prepared catalyst indicating indirectly that oxygen vacancies are created on substitution of $\mathrm{Pd}^{2+}$ into $\mathrm{Ce}^{4+}$ site into the lattice of $\mathrm{CeO}_{2}$.

To understand the oxygen storage capacity of $\mathrm{Pd} / \mathrm{CeO}_{2}$ catalyst, $\mathrm{H}_{2}$-TPR is carried out where the uptake of

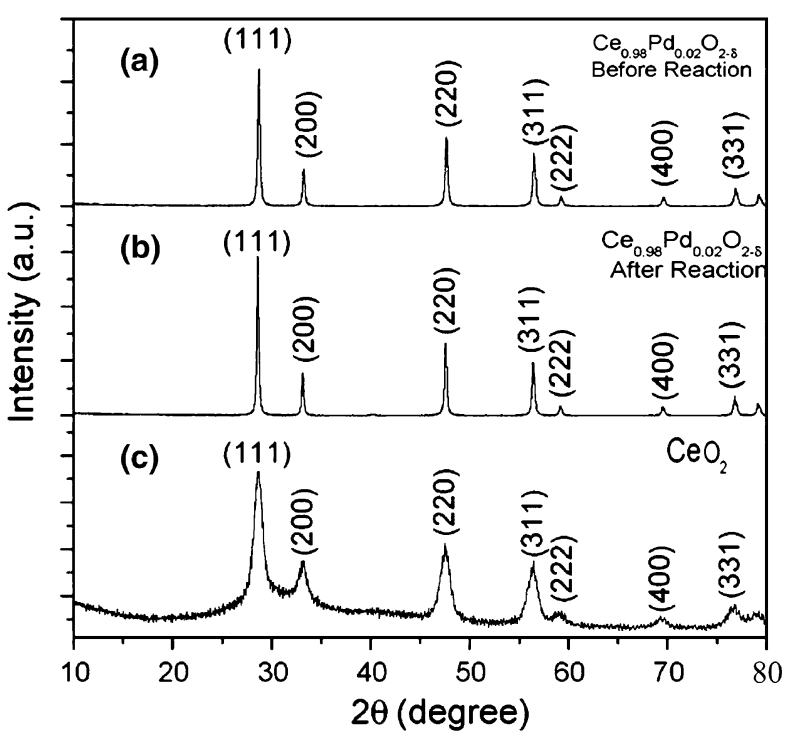

Fig. 2 XRD pattern of combustion synthesized nanocrystalline $\mathrm{CeO}_{2}$ and $\mathrm{Pd}$ ion-doped $\mathrm{CeO}_{2}$ 


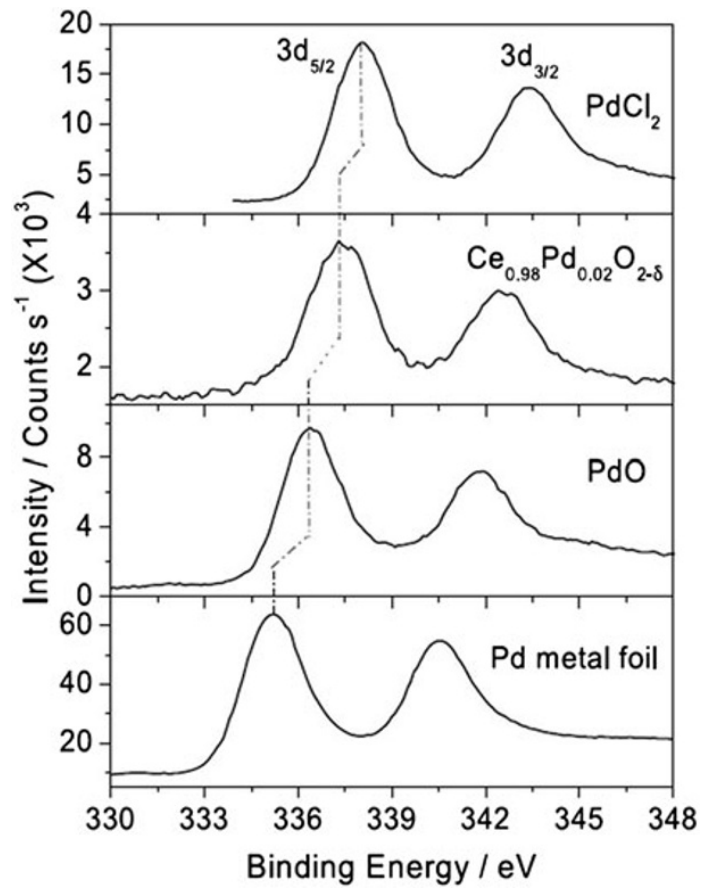

Fig. 3 XPS spectrum of Pd ion-doped ceria (from Ref. [10], with the permission of the corresponding author)

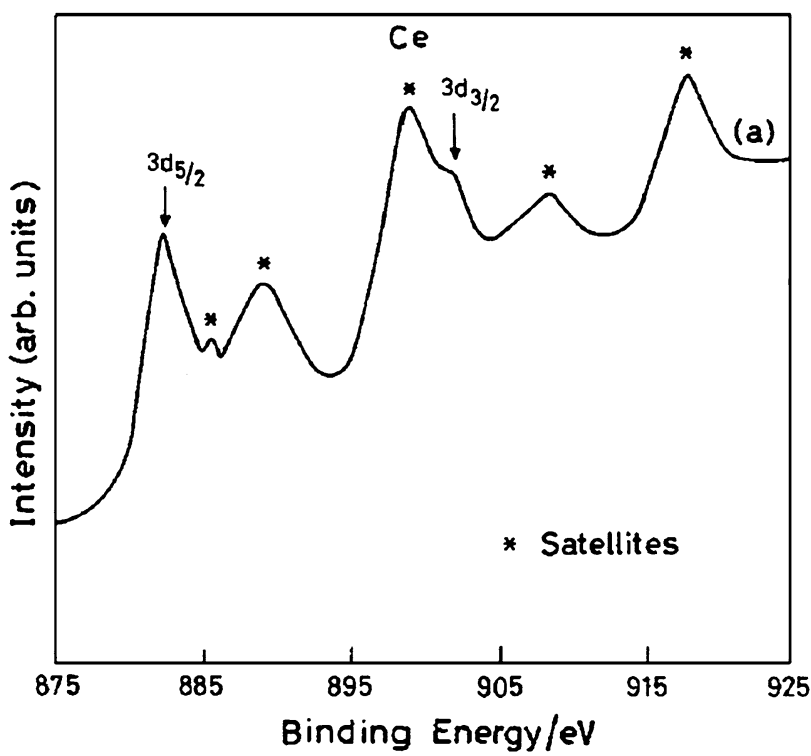

Fig. 4 XPS spectrum of Ce in Pd ion-doped ceria. (from Ref. [10], with the permission of the author)

hydrogen is measured as a function of temperature. It is depicted in Fig. 5. Pure $\mathrm{CeO}_{2}$ shows the uptake from about $350{ }^{\circ} \mathrm{C}$ until a peak at $500{ }^{\circ} \mathrm{C}$, whereas the Pd ion-doped $\mathrm{CeO}_{2}$ uptakes hydrogen at a much lower temperature of $65{ }^{\circ} \mathrm{C}$, a situation favourable for OSC.

These ionic catalysts are tested for various catalytic reactions. $\mathrm{CO}$ oxidation reaction is shown in Fig. 6. It is

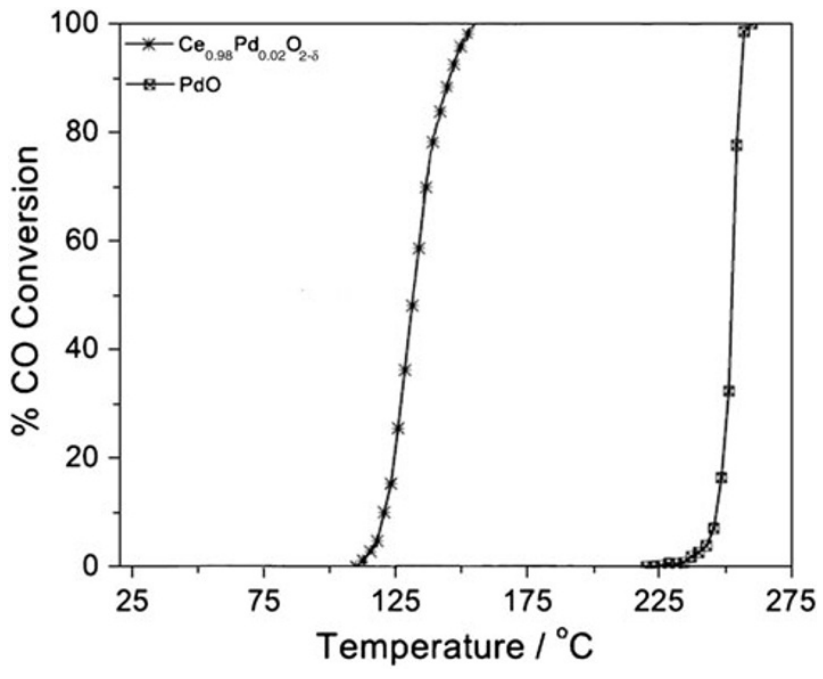

Fig. 5 Hydrogen TPR of OSC (from Ref [10], with the permission of the corresponding author)

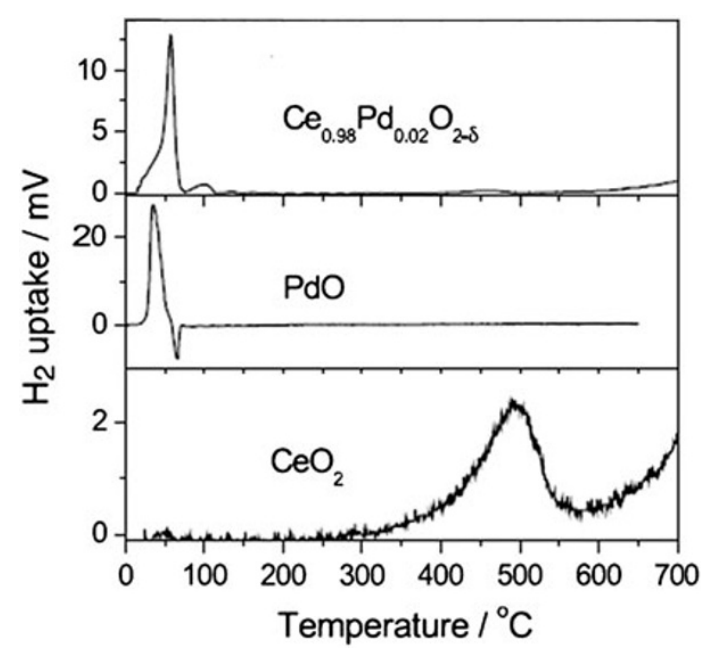

Fig. $6 \mathrm{CO}$ oxidation reaction of $\mathrm{Pd}$ ion dispersed ceria along with $\mathrm{PdO}$ (from Ref. [10], with the permission of the corresponding author)

very evident from the figure that $\mathrm{Pd}$ ion-substituted ceria exhibits the highest $\mathrm{CO}$ conversion with the lowest activation energies compared to $\mathrm{PdO}$ revealing that $\mathrm{Pd}$ iondoped $\mathrm{CeO}_{2}$ is an efficient OSC. The rates of conversion are 20-30 times higher than the corresponding metal particles impregnated catalysts [10] and their activation energies could be obtained from Arrhenius plots of the temperature dependence of reaction rates. These catalysts have been tested for $\mathrm{NO}_{x}$ reduction also [11]. Using first principle density functional theory (DFT), it is shown that $\mathrm{CO}$ adsorption in these catalysts occurs at the ionic sites of $\mathrm{Pd}^{2+}$, with a decrease in the net energy of the system [12]. 


\section{Conclusion}

$\mathrm{Pd}^{2+}$-dispersed $\mathrm{CeO}_{2}$ oxygen storage catalysts have been synthesized by solution combustion method resulting in noble metal ions dispersed OSC. We have shown that these ionically dispersed catalysts are catalytically more active towards exhaust emission reactions like $\mathrm{CO}$ oxidation.

Acknowledgments The author thanks KOPRC for the invitation to 2nd KACST-Oxford forum meeting at Riyadh in 2012.

Open Access This article is distributed under the terms of the Creative Commons Attribution License which permits any use, distribution, and reproduction in any medium, provided the original author(s) and the source are credited.

\section{References}

1. Gandhi HS, Graham GW, McCabe RW (2003) Automotive exhaust catalysts. J Catal 216:433-442

2. Yao HC, Yu Yao YF (1984) Ceria in automotive exhaust catalysts I. Oxygen storage. J Catal 86:254-258
3. Taylor KC (1993) Nitric oxide catalysis on automotive exhaust system. Catal. Rev. Sci. Eng. 35:457-481

4. Kaspar J. Graziani, Fornasia P (2000) Ceria containing three way catalysts. In: Gschneidner KA Jr, Eyring L (eds) Hand book on the physics and chemistry of rare earths, vol 29. Elsevier, Amsterdam, pp 159-267

5. Kaspar J, Fornasiero P, Hickey N (2003) Automotive catalytic converters: present status and some perspective. Catal Today 77:419-449

6. Ranga Rao G (1999) Influence of metal particles on the reduction properties of ceria based materials studies by TPR. Bull Mater Sci 22:89-94

7. Ranga Rao G, Kaspar J, Merioni S, Monte RD, Graziani M (1994) NO decomposition over partially reduced metallized $\mathrm{CeO}_{2}$ $-\mathrm{ZrO}_{2}$ solid solution. Catal Lett 24:107-112

8. Vijayaraghavan $\mathrm{R}$ et al (unpublished results on ceria based perovskite catalysts)

9. Sarma DD, Hegde MS, Rao CNR (1981) Study of surface oxidation of rare-earth metals by photoelectron spectroscopy. J Chem Soc Faraday Trans 277:1509-1520

10. Bera Parthssarathy, Hegde MS (2010) Recent advances in auto exhaust catalysts. J. Indian Inst Sci 90-2:299-325

11. Hegde MS, Madras Giridhar, Patil KC (2009) Noble metal ionic catalysts. Acc Chem Res 42:704-712

12. Dutta G, Gupta A, Waghmure UV, Hegde MS (2011) CO adsorption in ionic $\mathrm{Pt}, \mathrm{Pd}$ and $\mathrm{Cu}$ sites in $\mathrm{Ce} 1-\mathrm{xMxO}-\delta$ $(\mathrm{M}=\mathrm{Pt} 2+, \mathrm{Pd} 2+, \mathrm{Cu} 2+)$ J Chem Sci 123:509-516 